\title{
DAMPAK POLUSI UDARA DALAM RUANGAN PADA KEJADIAN KASUS PNEUMONIA: SEBUAH REVIEW
}

\author{
Bahri $^{\left.1^{*}\right)}$; Mursid Raharjo ${ }^{2}$; Suhartono ${ }^{3}$ \\ 1, 2,3) Fakultas Kesehatan Masyarakat ; Universitas Diponegoro \\ Jl. Prof. Soedarto, SH. ; Tembalang ; Semarang
}

\begin{abstract}
Abstrak
Polusi udara dalam ruangan merupakan masalah kesehatan yang serius karena menjadi penyebab 4,5 juta kematian tahunan secara global akibat pneumonia (12\%), stroke $(34 \%)$, penyakit jantung iskemik (26\%), penyakit paru obstruktif kronik (22\%), dan kanker paru-paru (6\%). Pneumonia adalah penyebab kematian menular terbesar pada anak-anak di seluruh dunia. Pneumonia menewaskan 808.694 anak di bawah usia 5 tahun pada tahun 2017. Tujuan penelitian ini adalah menjelaskan dampak polusi udara dalam ruangan pada kejadian kasus pneumonia. Ini adalah tinjauan literatur dari beberapa jurnal. Polusi udara dalam ruangan terdiri dari debu (PM10, PM2.5), kotoran atau gas (gas CO, NO dan SO) di udara dalam gedung seperti rumah atau tempat kerja yang merugikan jika kita menghirupnya. Paparan jangka panjang polusi udara dalam ruangan bisa menyebabkan pneumonia dan masalah kesehatan lainnya. Meningkatkan kualitas udara dalam ruangan dengan pengendalian sumber untuk menghindari emisi dalam dan luar ruangan, penyediaan ventilasi yang memadai dan teknologi pembersihan udara dapat diprioritaskan untuk mencegah kejadian kasus pneumonia.
\end{abstract}

Kata kunci: kasus pneumonia; polusi ruangan; udara

\begin{abstract}
[IMPACT OF INDOOR AIR POLLUTION ON PNEUMONIA CASE EVENTS: A REVIEW] Indoor air pollution is a serious health problem it causes 4.5 million annual deaths globally from pneumonia $(12 \%)$, stroke $(34 \%)$, ischemic heart disease $(26 \%)$, chronic obstructive pulmonary disease $(22 \%)$, and lung cancer $(6 \%)$. Pneumonia is the leading cause of infectious death in children worldwide. Pneumonia killed 808,694 children under the age of 5 in 2017. The aim of this study was to explain the impact of indoor air pollution on the incidence of pneumonia cases. This is a literature review of several journals and books. Indoor air pollution consists of dust, dirt or gas in the air inside buildings such as homes or workplaces which harm us if we breathe it which includes $\mathrm{PM}_{10}, \mathrm{PM}_{2.5}$, $\mathrm{CO}, \mathrm{NO}$ and $\mathrm{SO}$ gases. Long term exposure to indoor air pollution can cause pneumonia, stroke, ischemic heart disease, chronic obstructive pulmonary disease (COPD), lung cancer, and other problems. Improving indoor air quality by controlling sources to avoid indoor and outdoor emissions, providing adequate ventilation and air cleaning technology can be prioritized to prevent the incidence of pneumonia cases.
\end{abstract}

Keywords: pneumonia; indoor pollution; air

\section{Pendahuluan}

Penyakit berbasis lingkungan masih menjadi masalah kesehatan masyarakat dunia, salah satunya pneumonia (Novita Aris Pramudiyani, 2011). Pneumonia adalah infeksi akut yang mengenai jaringan paru-paru (alveoli) yang dapat disebabkan oleh berbagai

*) Correspondence Author (Bahri)

E-mail: bhrdnk@gmail.com mikroorganisme seperti virus, jamur dan bakteri (Kemenkes RI, 2019). Pneumonia adalah penyebab kematian menular terbesar pada anak-anak di seluruh dunia. Pneumonia menewaskan 808.694 anak di bawah usia 5 tahun pada tahun 2017 (WHO, 2021). Di Indonesia, pneumonia merupakan penyebab kematian nomor tiga setelah Kardiovaskuler dan TBC. Kasus pneumonia ditemukan paling banyak menyerang anak balita, dari 100 balita pneumonia 
diperkirakan 3 diantaranya meninggal. Hal inilah yang menyebabkan pneumonia merupakan masalah kesehatan penting di Indonesia dan dunia (Anika Ardia, Noraida, 2019). Indonesia termasuk peringkat ke-8 dalam 15 negara dengan angka kematian pneumonia balita tertinggi yaitu 22.000 kematian balita per tahun (Syani \& Raharjo, 2015).

Faktor risiko yang berhubungan dengan kejadian pneumonia terbagi atas dua kelompok besar yaitu faktor instrinsik dan faktor ekstrinsik. Faktor instrinsik meliputi umur, jenis kelamin, status gizi, berat badan lahir rendah, status imunisasi, pemberian ASI dan pemberian vitamin A. Faktor ekstrinsik meliputi kepadatan tempat tinggal, polusi udara, tipe rumah, ventilasi, kelembaban, letak dapur, jenis bahan bakar, kepadatan tempat tinggal, polusi udara, tipe rumah, ventilasi, kelembaban, letak dapur, jenis bahan bakar, penggunaan obat nyamuk, asap rokok, penghasilan keluarga serta faktor ibu baik pendidikan, umur ibu, maupun pengetahuan ibu (Caesar \& W, 2015).

Polusi udara dalam ruangan merupakan masalah kesehatan yang serius karena menjadi penyebab 4,5 juta kematian tahunan secara global akibat pneumonia $(12 \%)$, stroke $(34 \%)$, penyakit jantung iskemik $(26 \%)$, penyakit paru obstruktif kronik (22\%), dan kanker paru-paru (6\%). Polusi udara dalam ruangan telah dipelajari secara ekstensif di rumah, rumah sakit, perkantoran, restoran dan kereta api. Namun, polusi udara dalam ruangan terus menjadi masalah global, terutama di negara berkembang. Studi penelitian telah menunjukkan bahwa sekitar 90\% waktu dihabiskan di lingkungan dalam ruangan, 5 kali lebih tinggi dari rata-rata waktu yang dihabiskan di lingkungan luar ruangan yang menunjukkan besarnya risiko kesehatan manusia yang ditimbulkan oleh polutan udara dalam ruangan. Polutan udara dalam ruangan ini umumnya berasal dari lingkungan sekitar. (Amoatey et al., 2019). Pencemaran udara rumah tangga dapat berasal dari berbagai sumber seperti pemanas, memasak, asap rokok, bahan bangunan dan konstruksi, perabotan, produk konsumen yang digunakan untuk pembersihan, pemolesan atau perawatan pribadi, gas alami seperti radon, serta lembab dan jamur (Guercio et al., 2021).

Sekitar setengah dari populasi dunia yang tinggal di negara-negara berkembang membakar bahan bakar biomassa, yang melepaskan karbon monoksida (CO), particulate matter (PM), dan senyawa organik lainnya ke lingkungan hidup. Penelitian sebelumnya memiliki menunjukkan hubungan antara paparan materi partikulat dalam ruangan, terutama $\mathrm{PM}_{2.5}$ (diameter $<2.5$ $\mu \mathrm{m})$ dengan prevalensi pneumonia pada balita (Wu et al., 2020). Tujuan dari penelitian ini adalah menjelaskan dampak polusi udara dalam ruangan pada kejadian kasus pneumonia.

\section{Metode}

Penelitian ini menggunakan metode studi pustaka. Pencarian sumber data dilakukan dengan menggunakan kata kunci: pneumonia, polusi udara, lingkungan, PM10, PM2.5, indoor air dan pollution. Basis data diambil dari artikel yang diterbitkan di Google Scholar, Researchgate, WHO dan Elsevier. Data penelitian didapatkan sebanyak 72 artikel yang berkaitan dengan pneumonia. Hasil penelitian dipersempit dan diambil mulai tahun 2010-2020, hal ini dikarenakan untuk menjaga keterbaruan informasi. Kriteria inklusi penelitian menilai faktor risiko penyebab pneumonia menggunakan data primer. Kriteria ekslusi penelitian membahas pneumonia pada balita. Sehingga sampel dari penelitian didapatkan 13 artikel yang akan dibahas dalam literatur review.

\section{Hasil dan Pembahasan}

Kualitas udara yang baik dalam rumah merupakan faktor predisposisi terjadinya penyakit pneumonia, sehingga pemerintah mengatur nilai baku mutu ruangan yang tercantum dalam Peraturan Menteri Kesehatan No. 1077 Tahun 2011. Dalam Peraturan Menteri Kesehatan tersebut dijelaskan nilai baku mutu udara ruang didasarkan pada parameter kimia, fisik dan biologi. Parameter kimia terdiri atas $\mathrm{SO}_{2}$, $\mathrm{NO}_{2}, \mathrm{CO}, \mathrm{CO}_{2}, \mathrm{~Pb}$, asbes, formaldehide, volatile organic compound (VOC) dan environmental tobacco smoke. Parameter fisik yaitu suhu, pencahayaan, kelembaban, laju ventilasi, $\mathrm{PM}_{10}$ dan $\mathrm{PM}_{2.5}$, sedangkan parameter biologi yaitu jamur, bakteri patogen dan angka kuman (Permenkes, 2011).

Parameter kimia, biologi dan fisik tersebut saling berkaitan. Hal ini terbukti dari sebuah penelitian yang memperlihatkan bahwa pada anak usia dibawah lima tahun sampai usia 10 tahun memiliki risiko mengalami gangguan saluran pernafasan sebanyak $20 \%$ setiap kenaikan $\mathrm{NO}_{2} 28,3 \mu \mathrm{g} / \mathrm{m}^{3}$, dan berhubungan sangat kuat ( $\mathrm{p}$ $<0,01$ ) apabila pajanan $\mathrm{NO}_{2}$ disertai dengan pajanan asap rokok diatas $1,5 \mu \mathrm{g} / \mathrm{m}$ (Fahimah et al., 2014).

Variabel yang telah dikonfirmasi oleh penelitian sebelumnya yang memiliki hubungan signifikan dengan pneumonia yaitu kepadatan hunian, polusi udara dalam ruangan, ventilasi 
rumah, kelembaban rumah, kecukupan penerangan rumah, suhu rumah (Ardilla et al., 2019), usia terlalu muda, status imunisasi yang kurang, status gizi yang tidak baik, pemberian ASI yang kurang, lantai rumah yang terbuat dari tanah, adanya polusi dari dapur dikarenakan penggunaan kayu bakar, polusi asap rokok, polusi dari obat anti nyamuk bakar dan juga dipengaruhi oleh kebiasaan perilaku hidup sehat di dalam keluarga (Henny et al., 2013).

\subsection{Polusi udara dalam ruangan}

Polusi udara dalam ruangan yang kita hadapi saat ini sangat berbeda dan secara kimiawi lebih beragam dari yang dialami 40 tahun lalu. Bahan konstruksi yang lebih tua dan relatif lembab telah diganti dengan produk baru yang secara teknologi lebih rumit (misalnya polimer, cat berperforma tinggi). Selain itu, pengembangan teknik dan desain bangunan baru yang ditujukan untuk penghematan energi yang efektif dapat menghasilkan ruang dalam ruangan yang kedap udara dengan ventilasi yang tidak memadai (Kelly \& Fussell, 2019).

Polusi udara dalam ruangan terdiri dari debu, kotoran atau gas di udara di dalam gedung seperti rumah atau tempat kerja yang merugikan kita jika kita menghirupnya. Jenis polusi udara meliputi: PM (partikel mikroskopis dari debu dan kotoran di udara), gas CO, NO dan SO. Polusi udara dalam ruangan bisa disebabkan oleh banyak hal diantaranya: cara menghangatkan ruangan, cara yang digunakan untuk memasak, ventilasi yang buruk, kelembaban, penggunaan bahan kimia kimia dalam produk pembersih, beberapa bahan bangunan. (British Lung Foundation, 2021). Pajanan yang tinggi dapat terjadi pada wanita dan balita yang menghabiskan sebagian besar waktu mereka di dalam rumah (Purushothaman et al., 2020).

Paramater fisik rumah berupa Particulate meter berukuran $10 \mu \quad\left(\mathrm{PM}_{10}\right)$ berisiko meningkatkan kasus pneumonia dan akan lebih berbahaya pada saat musim panas dibandingkan pada saat musim hujan karena jumlahnya akan lebih besar. Selain itu, di Jepang angka kematian pada kasus pneumonia berhubungan signifikan dengan $\mathrm{PM}_{10}$ dan $\mathrm{PM}_{2,5}$. Kasus pneumonia berhubungan secara signifikan dengan asap rokok, $\mathrm{PM}_{2,5}$ dan CO. Kualitas udara dalam rumah dan kasus infeksi saluran pernafasan akut juga dilaporkan pada anak bawah lima tahun di Kanada, yaitu adanya hubungan signifikan terhadap kejadian infeksi saluran pernafasan setiap kenaikan $\mathrm{CO}_{2} 500$ ppm dengan OR 2,85 (Fahimah et al., 2014).

\subsection{Risiko polusi udara dalam ruangan pada tempat kerja}

Polusi udara dalam ruangan tidak hanya menjadi masalah di rumah, tapi juga bisa menjadi masalah di tempat kerja. Dalam beberapa pekerjaan, paparan konsentrasi polutan udara tertentu yang jauh lebih tinggi daripada di rumah atau adanya kontak dengan zat yang lebih berbahaya daripada yang ditemukan di rumah. Pada tempat kerja dapat terpapar zat yang dapat membuat saluran pernafasan menjadi lebih sensitif, beberapa penyebabnya diantaranya adalah cat semprot kendaraan tertentu, debu dari tepung, debu kayu, cairan pengerjaan logam dan bahan pembersih. Risiko lain dari polusi udara di tempat kerja termasuk serat asbes, asap las dan debu silika. Debu silika juga bisa berbahaya dan ditemukan pada produk seperti batu bata dan beton. Pengelasan adalah proses industri umum yang melepaskan materi partikulat halus dan gas beracun. Jika bekerja sebagai pembersih, pekerja juga akan terkena senyawa organik yang mudah menguap yaitu VOC. Sebuah penelitian barubaru ini menemukan bahwa wanita yang bekerja sebagai pembersih mengalami peningkatan penurunan fungsi paru-parunya (British Lung Foundation, 2021).

Pencemaran udara di tempat kerja disebabkan oleh berbagai macam hal seperti debu anorganik dan debu organik. Salah satu industri yang menghasilkan debu adalah industri perkayuan. Industri kayu mampu menghasilkan serbuk kayu. Debu kayu termasuk dalam jenis debu organik yang dapat menyebabkan seorang pekerja industri kayu terkena gangguan faal paru. Proses pengolahan kayu seperti pemotongan, penggergajian dan pengamplasan dapat menghasilkan serbuk kayu dengan berbagai ukuran. Besar kecilnya debu kayu inilah yang akan mempengaruhi resiko kecil yang ditimbulkan terhadap kesehatan pekerja (Nikmah, 2020).

Dampak debu organik di udara terhadap kesehatan tenaga kerja adalah bronchitis, asma, Kanker paru, pneumonia dan lain lain. Upaya untuk mengurangi dampak debu terhadap kesehatan tenaga kerja adalah mengurangi hal tersebut adalah dengan melakukan shielding, penggunaan Alat Pelindung Diri (APD), mengurangi faktor risiko potensial lainnya seperti merokok, dan riwayat penyakit paru (Nugrahaeni et al., 2004) 
3.3 Dampak polusi udara dalam ruangan terhadap kejadian pneumonia

Anak-anak sangat rentan terhadap kualitas udara dalam ruangan yang buruk karena paruparu mereka masih berkembang. Saluran udara mereka lebih kecil, sehingga peradangan yang disebabkan oleh polusi dapat menyebabkan saluran udara lebih mudah menyempit daripada pada orang tua. Polusi juga dapat berinteraksi dengan alergen penyebab asma pada anak (British Lung Foundation, 2021). Paparan jangka panjang polusi udara dalam ruangan bisa menyebabkan pneumonia, stroke, penyakit jantung iskemik, penyakit paru obstruktif kronis (PPOK), kanker paru-paru, dan masalah lain (Dewiningsih, 2018).

Pneumonia dapat menyebar dengan berbagai cara. Virus dan bakteri yang biasa ditemukan di hidung atau tenggorokan anak, dapat menginfeksi paru-paru jika terhirup. Mereka juga dapat menyebar melalui tetesan yang terbawa udara dari batuk atau bersin. Selain itu, pneumonia dapat menyebar melalui darah, terutama selama dan segera setelah lahir. Penelitian lebih lanjut perlu dilakukan pada berbagai patogen penyebab pneumonia dan cara penularannya, karena ini sangat penting untuk pengobatan dan pencegahan (WHO, 2021).

\subsection{Penyebab kualitas udara dalam ruangan buruk}

Kualitas udara dalam rumah dipengaruhi oleh kondisi fisik rumah yang memenuhi syarat rumah sehat, yaitu rumah yang memenuhi kebutuhan psikologis dan biologis, persyaratan pencegahan penularan penyakit dan kecelakaan. Anak dibawah lima tahun yang terpajan dengan bahan bakar emisi sisa proses pembakaran berisiko 3 kali lipat dibandingkan anak bawah lima tahun yang tidak terpajan. Ventilasi udara di dapur berhubungan dengan pengurangan konsentrasi emisi partikel asap dari sisa pembakaran $(p<0,05)$. Kepemilikan ventilasi di dapur dipengaruhi oleh pendidikan dan kepemilikan lahan yang digunakan untuk rumah (Fahimah et al., 2014). Bakteri penyebab penyakit pneumonia akan semakin tumbuh aktif pada rumah yang kondisi lingkungan udara ataupun lingkungan fisik yang buruk (Mulyani, 2020).

Polusi udara dalam ruangan dapat dipahami dengan baik di komunitas pedesaan. Masalah kritis yang mendasar adalah bagaimana masyarakat memilih bahan bakar yang paling cocok untuk mereka. Penggunaan model linier bahan bakar berganda menemukan faktor-faktor yang penting untuk keputusan rumah tangga dalam pemilihan bahan bakar: keekonomisan bahan bakar, jenis kompor dan kondisi akses ke bahan bakar, karakteristik teknis kompor dan praktik memasak; preferensi budaya; dan dampak kesehatan (Huboyo, 2015).

\subsection{Meningkatkan kualitas udara dalam ruangan}

Pencegahan adalah intervensi yang paling murah untuk mengurangi penyakit terkait pneumonia dan kematian pada anak-anak. Baik negara berkembang maupun negara maju telah mencapai pengurangan substansial dalam beban penyakit pneumonia selama 10 tahun terakhir yang mencerminkan kondisi sosial ekonomi yang lebih baik, akses yang lebih baik pada pelayanan kesehatan dan implementasi imunisasi yang lebih luas terhadap Haemophilus influenzae tipe $b$ (Hib), campak, rejan batuk (pertusis) dan Streptococcus pneumoniae (Nguyen et al., 2020).

Tindakan yang dapat dilakukan untuk mencegah polusi udara dalam ruangan diantaranya adalah menjaga kondisi lingkungan rumah dan kamar agar tidak menjadi tempat perkembangbiakan virus dan bakteri dengan cara memfungsikan ventilasi rumah sebagaimana mestinya, yaitu dengan membuka jendela di pagi hari. Rumah atau kamar yang luastanpa sirkulasi udara yang baik tetap akan menjadi tempat berkembang biak virus dan bakteri (Fahimah et al., 2014). Perilaku Hidup Bersih dan Sehat (PHBS) harus dipraktikkan di semua bidang kesehatan masyarakat karena pada hakikatnya setiap masalah kesehatan merupakan hasil perilaku, yaitu interaksi manusia (host) dengan bibit penyakit atau pengganggu lainnya (agent) dan lingkungan (environment) (Kemenkes RI, 2016).

Tiga strategi dasar yang direkomendasikan secara luas untuk meningkatkan kualitas udara dalam ruangan adalah pengendalian sumber untuk menghindari emisi dalam dan luar ruangan, penyediaan ventilasi yang memadai dan teknologi pembersihan udara untuk mencapai peningkatan lebih lanjut jika diperlukan. Walaupun mengurangi sumber polusi adalah pendekatan yang disukai secara universal, seringkali hal ini tidak memungkinkan dan ventilasi semakin menghadirkan tantangan dalam hal penggunaan energi bangunan dan karena udara luar yang bersih masih jauh dari yang diberikan dibanyak daerah di seluruh dunia. Oleh karena itu, penggunaan pembersih udara yang tidak melibatkan biaya energi untuk pergerakan dan pengkondisian udara luar ruangan semakin mendapat perhatian sebagai 
strategi untuk menghilangkan partikel dan gas yang tidak diinginkan (Kelly \& Fussell, 2019).

Kondisi udara rumah yang tercemar perlu dicegah untuk menurunkan kejadian pneumonia pada anak bawah lima tahun. United Nations Emergency Children's Fund (UNICEF) dan World Health Organization (WHO) menyatakan bahwa salah satu cara mencegah kejadian pneumonia pada anak bawah lima tahun adalah mengurangi pencemaran udara dalam rumah. Tindakan untuk mengurangi polusi udara tersebut adalah dengan mengurangi pajanan fisik, kimia dan biologi penyebab pneumonia. Pajanan polusi udara jangka panjang berhubungan dengan kejadian pneumonia anak bawah lima tahun karena anak bawah lima tahun lebih mudah terinfeksi pneumonia. Untuk menurunkan kasus pneumonia tersebut, tindakan utama yang perlu dilakukan adalah dengan mengurangi polusi udara (Fahimah et al., 2014). Pada anak yang terinfeksi HIV, antibiotik kotrimoksazol diberikan setiap hari untuk mengurangi risiko tertular pneumonia (WHO, 2021).

Sejumlah negara termasuk Bangladesh, India, Kenya, Uganda dan Zambia telah mengembangkan rencana distrik, negara bagian dan nasional untuk mengintensifkan tindakan pengendalian pneumonia dan diare. Banyak lagi yang telah mengintegrasikan tindakan khusus diare dan pneumonia ke dalam strategi kesehatan anak nasional dan kelangsungan hidup anak mereka. Bagi banyak negara, agenda Tujuan Pembangunan Milenium secara eksplisit memasukkan pengakhiran kematian akibat diare dan pneumonia yang dapat dicegah sebagai tindakan prioritas (WHO, 2021).

\section{Simpulan dan Saran}

Pembahasan dalam penelitian ini memiliki keterbatasan, variabel yang dibahas hanya faktor risiko lingkungan terhadap kejadian pneumonia pada balita. Paparan jangka panjang polusi udara dalam ruangan yang terdiri dari parameter kimia, fisik dan biologi. Parameter kimia terdiri atas $\mathrm{SO}_{2}$, $\mathrm{NO}_{2}, \mathrm{CO}, \mathrm{CO}_{2}, \mathrm{~Pb}$, asbes, formaldehide, VOC dan environmental tobacco smoke. Parameter fisik yaitu suhu, pencahayaan, kelembaban, laju ventilasi, $\mathrm{PM}_{10}$ dan $\mathrm{PM}_{2.5}$, sedangkan parameter biologi yaitu jamur, bakteri patogen dan angka kuman bisa menyebabkan pneumonia.

\section{Ucapan Terima Kasih}

Terima kasih disampaikan untuk semua penulis artikel yang telah berkenan membagi sebagian ilmu pengetahuannya.

\section{Daftar Pustaka}

Amoatey, P., Omidvarborna, H., Baawain, M. S., \& Al-Mamun, A. (2019). Indoor air pollution and exposure assessment of the gulf cooperation council countries: A critical review. Environment International, 121(August), 491-506.

Anika Ardia, Noraida, E. (2019). Perilaku Merokok Orangtua Dengan Kejadian ISPA Pneumonia Pada Balita. Jurnal Kesehatan Lingkungan, 1(1), 2019.

Ardilla, Y., Purnama Sari, I., \& Stia Budi, I. (2019). Residential Factors of Pneumonia: A Literature Review. Jurnal Ilmu Kesehatan Masyarakat, 10(3), 147-152.

British Lung Foundation. (2021). What is indoor air pollution?

https:// www.blf.org.uk/support-foryou/indoor-air-pollution/aboutindoor-air-pollution\#: :text=Indoor air pollution is dust,monoxide $\% 2 \mathrm{C}$ nitrogen oxides $\% 2 \mathrm{C}$ sulphur dioxide

Caesar, D. L., \& W, N. E. (2015). Hubungan Jumlah Bakteri Patogen dalam Rumah dengan Kejadian Pneumonia pada Balita di Wilayah Kerja Puskesmas Ngesrep Banyumanik Semarang Tahun 2014 Relationship. Jurnal Kesehatan Lingkungan Indonesia, 14(1), 21-26.

Dewiningsih. (2018). Faktor Lingkungan dan Perilaku Kejadian Pneumonia Balita Usia 12-59 Bulan. HIGEIA (Journal of Public Health Research and Development), 2(3), 453-464.

Fahimah, R., Kusumowardani, E., \& Susanna, D. (2014). Kualitas Udara Rumah dengan Kejadian Pneumonia Anak Bawah Lima Tahun (di Puskesmas Cimahi Selatan dan Leuwi Gajah Kota Cimahi. Makara Journal of Health Research, 18(1), 25-33.

Guercio, V., Pojum, I. C., Leonardi, G. S., Shrubsole, C., Gowers, A. M., Dimitroulopoulou, S., \& Exley, K. S. (2021). Exposure to indoor and outdoor air pollution from solid fuel combustion and respiratory outcomes in children in developed countries: a systematic review and meta-analysis. Science of the Total Environment, 755.

Henny, M., Sartika, D., Setiani, O., W, N. E., \& 
Amerika, D. (2013). Faktor Lingkungan Rumah Dan Praktik Hidup Orang Tua Yang Berhubungan Dengan Kejadian Pneumonia Pada Anak Balita Di Kabupaten Kubu Raya Tahun 2011. Jurnal Kesehatan Lingkungan Indonesia, 11(2), 153-159.

Huboyo, H. S. (2015). Household Characteristics and Potential Indoor Air Pollution Issues in Rural Indonesian Communities Using Fuelwood Energy. Jurnal Ilmu Lingkungan, 13(1), 27.

Kelly, F. J., \& Fussell, J. C. (2019). Improving indoor air quality, health and performance within environments where people live, travel, learn and work. Atmospheric Environment, 200(August 2018), 90-109.

Kemenkes RI. (2016). Pedoman Umum Program Indonesia Sehat Dengan Pendekatan Keluarga.

Kemenkes RI. (2019). Profil Kesehatan Indonesia Tahun 2019.

Permenkes No. 1077/Menkes/PER/2011 tentang Pedoman penyehatan udara dalam ruang rumah, (2011).

Mulyani, V. H. (2020). Healthy Household and Complete Basic Immunization as A Risk for Causes of Toddler Pneumonia in Jember Regency: Correlation Study. Jurnal Kesehatan Lingkungan, 12(1), 30.

Nguyen, T. K. P., Bui, B. B. S., Ngo, Q. C., Fitzgerald, D. A., Graham, S. M., \& Marais, B. J. (2020). Applying lessons learnt from research of child pneumonia management in Vietnam. Paediatric Respiratory Reviews.
Nikmah, F. (2020). Literature Review: Risk Factors Wood Dust Exposure on Workers Lung Status. Jurnal Kesehatan Lingkungan, 12(3), 200.

Novita Aris Pramudiyani, G. N. P. (2011). Hubungan Antara Sanitasi Rumah Dan Perilaku Dengan Kejadian Pneumonia Balita. Jurnal Kesehatan Masyarakat, 6(2), 71-78.

Nugrahaeni, F. S. S., Joko, T., \& Setiani, O. (2004). Analisis Faktor Risiko kadar debu Organik di udara terhadap Gangguan fungsi Paru pada Pekerja Industri Penggilingan Padi di Demak. Jurnal Kesehatan Lingkungan Indonesia, 3(2), 4145.

Purushothaman, S. K., Selvam, J., \& Muthunarayanan, V. (2020). Ambient indoor air pollution and its consecutive effect on environment materials and health. Materials Today: Proceedings, 37(Part 2), 504-508.

Syani, F. El, \& Raharjo, M. (2015). Hubungan Faktor Risiko Lingkungan Terhadap Kejadian Penyakit Pneumonia Balita Dengan Pendekatan Analisis Spasial Di Kecamatan Semarang Utara. Jurnal Kesehatan Masyarakat (e-Journal), 3(3), 732-744.

WHO. (2021). Pneumonia. https://www.who.int/newsroom/fact-sheets/detail/pneumonia

Wu, Z., Zhang, S., Tang, Y. T., Jiang, W., Jiang, H., Xie, Z., \& Zhang, B. (2020). Indoor environment in relation to recurrent childhood pneumonia in Southern China. In Building and Environment. 